\title{
ASSESSMENT OF THE MICROBIAL POLLUTION OF THE OLYMPIC ROWING AND CANOEING CENTER AT SCHINIAS THROUGH MATHEMATICAL MODELING
}

\author{
E. ROMAS \\ C. NOUTSOPOULOS \\ A. ANDREADAKIS *
}

\author{
Department of Water Resources \\ Faculty of Civil Engineering \\ National Technical University of Athens \\ 5 Iroon Polytechniou str., Zografou 15773, Athens, Greece
}

Selected from papers presented in $9^{\text {th }}$ International Conference on Environmental Science and Technology (9CEST2005)

1-3 September 2005, Rhodes island, Greece *to whom all correspondence should be addressed e-mail: andre1@central.ntua.gr

\begin{abstract}
The Olympic Rowing and Canoeing Center constructed at Schinias, accommodated the rowing and canoe - kayak sprint competition of the 2004 summer Olympic Games. This paper presents the results of a study which aimed at assessing the water quality characteristics, regarding microbial pollution, of the Olympic rowing and canoeing Center in relation to alternative inflows scenarios. The study was conducted by using a microbial pollution model which describes both physical transport phenomena and biological and chemical reactions taking place in the water body. Moreover, the mathematical model incorporates a stochastic approach (based on Monte Carlo technique) in order to take into account the random variation of the input variables, such as the pollution loads and the intensity of the solar radiation, which is an essential factor for the fate of faecal coliforms.

The mathematical model takes into consideration the random fluctuation of the constants and the model's input data, by creating a range of possible values for each one of them and a corresponding probability distribution. As a result of this kind of stochastic approach, the model predicts the concentration of faecal coliforms, not as a single value, but as a set of possible values. A statistical analysis of this set of values, allows for the estimation of statistical data like characteristic values that will not be exceeded for given confidence levels.

The mathematical model was applied for a wide range of the monthly inflows entering the rowing center through the leading channel, which fully cover the discharges of Makaria spring for three alternative typical hydrologic years (a particularly wet, a particularly dry and a mean hydrological year).

From the application of the model for several flow patterns into the course it was concluded that the flow pattern does not affect significantly the spatial and temporal distribution of the concentration of the faecal coliforms, since dispersion is the governing transport mechanism in the rowing course. The highest concentrations are observed in an area close to the inlet point of the leading channel, while in areas located in a longer distance the concentrations are decreasing.

According to the results of the model the anticipated concentration of faecal coliforms, in relation to the proposed revision of the 76/160 European Directive on bathing waters, is lower than $250 \mathrm{FC} / 100 \mathrm{ml}$ for the $95 \%$ of the samples and thus the rowing and canoeing center is sorted in the category of excellent quality waters.
\end{abstract}

KEYWORDS: faecal coliforms, mathematical model, microbial pollution, Monte Carlo 


\section{INTRODUCTION}

The rowing and canoe - kayak sprint competition of the 2004 summer Olympic Games was held at the Olympic Rowing and Canoeing Center at Schinias. The lake consists of two parallel courses, connected through a short channel at the north and a curved channel about $1 \mathrm{~km}$ long at the south. The main course is about $2.5 \mathrm{~km}$ long, has a trapezoidal section with bottom width $120 \mathrm{~m}$ and depth $3.5 \mathrm{~m}$, while the auxiliary course is about $1.5 \mathrm{~km}$ long with a depth of $2.0 \mathrm{~m}$ (Figure 1). The lake is supplied with water from the Makaria spring through a leading channel and it is discharged to the adjacent wetland through two weirs.

This paper presents the results of a study which aimed at assessing the water quality characteristics of the Olympic rowing and canoeing Center, with respect to microbial pollution, through mathematical modelling.

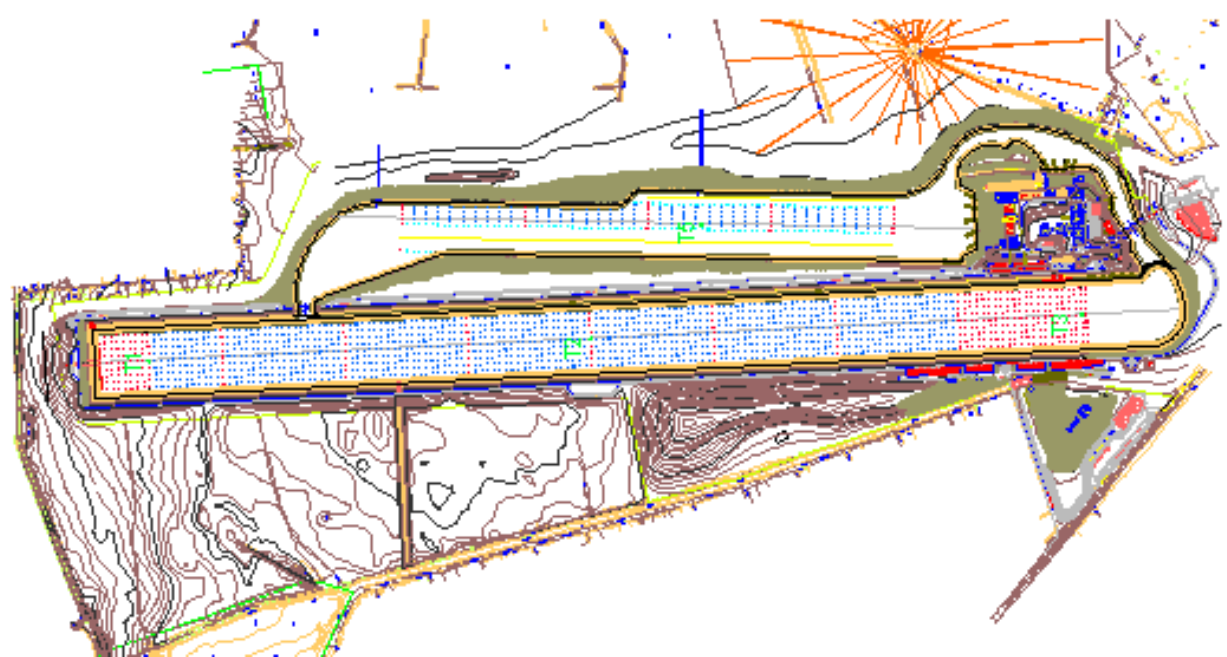

Figure 1. Layout of the Olympic Rowing and Canoeing Center at Schinias

\section{METHODOLOGY - PRESENTATION OF THE MODEL Methodology}

The study was conducted by developing a microbial pollution model which describes the advective and dispersive transport of faecal coliforms as well as biological and chemical reactions taking place in the water body. It also incorporates a stochastic approach (based on Monte Carlo technique) in order to take into account the random variation of the input variables and the kinetic constants.

Many of the model's input data such as the pollution loads of the inflows and the intensity of solar radiation, which plays an essential role in the fate of faecal coliforms, exhibit a stochastic character and are governed by laws which can not be precisely quantified. Furthermore there is a high level of uncertainty when determining the appropriate values of the constants employed in the model's kinetic equations. Most of these values are derived through experimental procedures conducted under different conditions and the range between the values of each parameter that independent researchers suggest is often wide.

The mathematical model takes into consideration the random fluctuation of the constants and the model's input data, by creating a range of possible values for each one of them and a corresponding probability distribution. The value of each parameter is then selected, with a pseudo-random way, through the specific probability distribution which can be log-normal or uniform.

As a result of this kind of stochastic approach, the values of the predicted variable are different, even at the same time period of two successive simulated years, given that the values of the parameters vary randomly. The simulation of the water body's condition is continued for a long time period, until the number of the obtained values of the predicted 
variables is large enough and the statistical parameters of the sample, such as average value and standard deviation, have been stabilized. For the specific study the repetition of the yearly simulation 120 times, was considered satisfactory. This procedure is based on the Monte Carlo technique and gives a dynamic solution to the problem of uncertainty which is involved in environmental models.

The model predicts the concentration of faecal coliforms, not as a single value, but as a set of possible values. A statistical analysis of this set of values, allows for the estimation not only of the average coliforms concentrations, but also of additional statistical data like characteristic values that will not be exceeded for given confidence levels.

\section{General Structure of the Mathematical Model}

The mathematical model describes various physical, chemical and biological processes taking place in a water body, through suitable terms in mass balance equations for each chemical biological and physical parameter examined. Direct solution of these equations is usually impossible for natural systems. By considering the water body as a network of finite completely mixed cells connected by dispersive and convective terms, the continuity equation in finite difference form can be written as:

$$
\mathrm{V}_{\mathrm{k}} \frac{\mathrm{d} \mathrm{C}_{\mathrm{k}}}{\mathrm{dt}}=\sum_{\mathrm{j}}\left|-\mathrm{Q}_{\mathrm{kj}} \cdot\left(\mathrm{a}_{\mathrm{kj}} \cdot \mathrm{C}_{\mathrm{k}}+\beta_{\mathrm{kj}} \cdot \mathrm{C}_{\mathrm{j}}\right)+\mathrm{E}_{\mathrm{kj}}^{\prime} \cdot\left(\mathrm{C}_{\mathrm{j}}-\mathrm{C}_{\mathrm{k}}\right)\right| \pm \mathrm{r}_{\mathrm{k}}+\mathrm{w}_{\mathrm{k}}
$$

where

$\mathrm{C}_{\mathrm{k}}=$ concentration in cell $\mathrm{k}\left(\mathrm{mg} \mathrm{l}^{-1}\right) \quad \mathrm{C}_{\mathrm{j}}=$ concentration in cell $\mathrm{j}$ contacted with cell k $\left(\mathrm{mg} \mathrm{l}^{-1}\right)$

$V_{k}=$ volume of cell $k\left(m^{3}\right) \quad Q_{k j}=$ net advective flow from cell $k$ to cell $j\left(m^{3}\right.$ day $\left.{ }^{-1}\right)$

$E_{k j}=$ dispersion coefficient $\left(m^{2}\right.$ day $\left.^{-1}\right) A_{k j}=$ cross sectional area between cell $k$ and $j\left(m^{2}\right)$

$E^{\prime}{ }_{k j}=E_{k j} A_{k j} / L_{k j}\left(m^{3}\right.$ day $\left.^{-1}\right) \quad L_{k}=$ characteristic length of cell $k(m)$

$L_{j}=$ characteristic length of cell $j(m) L_{k j}=\left(L_{k}+L_{j}\right) / 2(m)$

$r_{k}=$ reaction term for cell $k\left(g_{\text {day }}{ }^{-1}\right) \quad w_{k}=$ external load into cell $k\left(g_{\text {day }}{ }^{-1}\right)$

$a_{k j}, \beta_{k j}=$ finite difference weighting factors (dimensionless), $\beta_{k j}=1-a_{k j}$

Using the above finite difference approach a set of mass balance equations was derived describing the transport and reaction phenomena regarding each species (faecal coliforms) within each completely mixed cell. The solution of these equations for dynamic conditions requires their numerical integration.

\section{Segmentation}

Taking into account the dimensions and the geometry of the rowing course as well as the results of the hydrodynamic simulation (Christodoulou et al., 2004), the water body was segmented into 37 completely mixed cells, with dimensions ranging from $100 \mathrm{~m} \times 100 \mathrm{~m}$ to $135 \mathrm{~m} \times 160 \mathrm{~m}$.

\section{Inflows - Pollution loads}

Since detailed data regarding the monthly flows entering the rowing course through the leading channel were not available, the mathematical model was applied for a wide range of inflows. The values of the inflows used in the model vary from 250 to $3600 \mathrm{~m}^{3} \mathrm{hr}^{-1}$ and fully cover the discharges of Makaria spring for the three alternative typical hydrologic years (a particularly wet, a particularly dry and a mean hydrological year), resulting from the hydrogeological study. The final water balance was estimated after considering the water losses due to evaporation from the lake's surface, the water addition due to rainfall and the flow pattern. 
The determination of the pollution loads entering the course through the leading channel was based on an extensive field work involving sampling and analyses, conducted at the Sanitary Engineering Laboratory of the National Technical University of Athens in the period April 2002 - December 2003. In the context of this monitoring program, water samples form the Makaria spring, the leading channel and various areas inside the rowing course were obtained and chemically analysed in order to determine faecal coliforms concentration.

No correlation was established between the faecal coliforms concentrations of the Makaria spring and those of the inlet point of the leading channel. Thus all the results of the chemical analyses were considered as a unified time series of the incoming concentrations of faecal coliforms into the course. However, a strong seasonal variation of faecal coliforms concentrations was observed both at the Makaria spring and the leading channel. The period of relatively high concentrations has duration of 6 months for the Makaria spring and 4 months for the leading channel while the period of lower concentrations has duration of 6 and 8 months respectively.

Following the statistical analysis of the laboratory results it was concluded that the entire set of faecal coliforms concentrations of the samples, can be efficiently described by a log-normal probability density function with mean value $\mu=2.06$ and standard deviation $\sigma=1.04$. In order to account for the seasonal variation 2 different probability density functions were created, through which the model, considering the time of simulation, selects randomly the concentrations of faecal coliforms in the inflow.

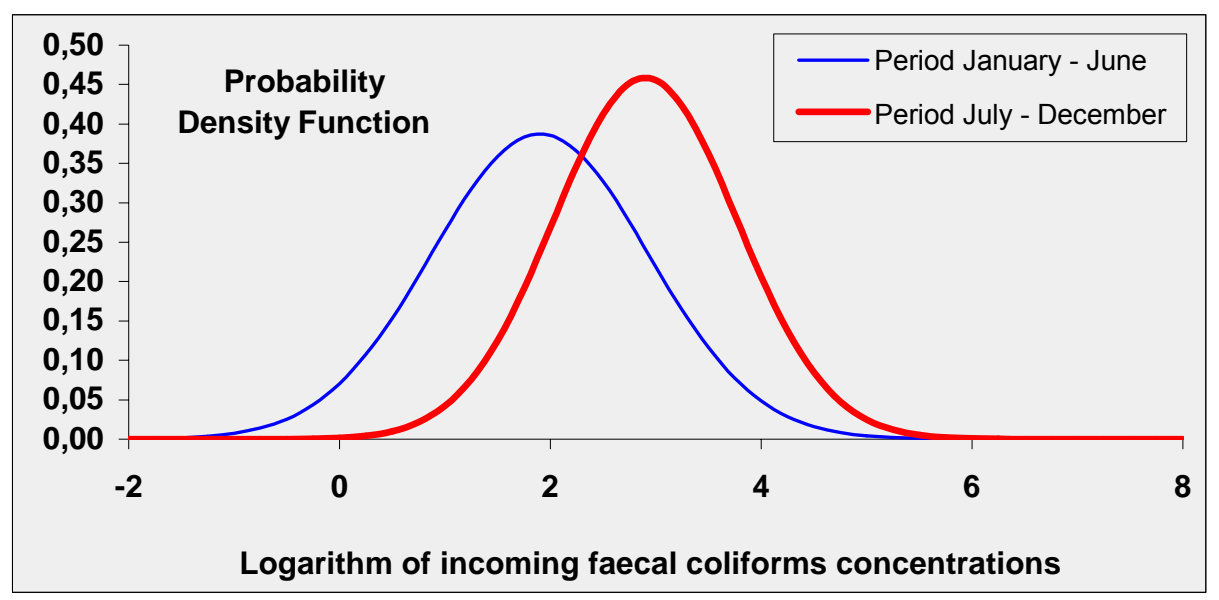

Figure 2. Probability distributions of incoming faecal coliforms concentrations used in the model

The density functions used in the model have the following characteristics:

Low concentrations period (January to June): the incoming concentrations of faecal coliforms into the rowing course follow a log-normal distribution with mean value $\mu=1.90$ and standard deviation $\sigma=1.03$. (Figure 2)

High concentrations period (July to December): the incoming concentrations of faecal coliforms into the rowing course follow a log-normal distribution with mean value $\mu=2.90$ and standard deviation $\sigma=0.87$. (Figure 2)

\section{Model Parameters and Reaction Kinetics}

Apart from dilution in the water mass, the decrease of faecal coliforms concentration is accomplished through decay. Under the assumptions of first order decay (Chick's law) and that faecal coliforms decay due to solar radiation is proportional to its intensity (Alkan et al., 1984) the following equation is derived: 
$\mathrm{N}=\mathrm{N}_{\mathrm{O}} \cdot \mathrm{e}^{\left(\mathrm{K}_{\mathrm{O}}+\mathrm{K}_{\mathrm{S}} \cdot \mathrm{w}_{\text {water }}\right) \cdot \Delta \mathrm{t}}$

$\mathrm{N}_{O}$ and $\mathrm{N}$ concentration of faecal coliforms at times $\mathrm{t}$ and $\mathrm{t}+\Delta \mathrm{t}$ respectively

$\mathrm{K}_{\mathrm{O}} \quad$ constant of decay rate in darkness $\left(\right.$ day $\left.^{-1}\right)$

$\mathrm{K}_{\mathrm{S}} \quad$ constant of decay rate due to solar radiation $\left(\mathrm{cm}^{2} \mathrm{cal}^{-1}\right)$

$I_{\text {water }} \quad$ average intensity of solar radiation in the water column (cal $\mathrm{cm}^{-2} \mathrm{day}^{-1}$ )

The range of values of the constants $\mathrm{K}_{\mathrm{O}}$ and $\mathrm{K}_{\mathrm{S}}$, which were obtained through literature research, was wide, so the selection of specific values for these constants, which would incorporate a high level of uncertainty in the model, was avoided by creating a uniform possibility distribution for each constant. The values of $\mathrm{K}_{\mathrm{O}}$ (Bellair et al., 1977) vary randomly from 0.028 to $0.042 \mathrm{hr}^{-1}$ while these of $\mathrm{K}_{\mathrm{S}}$ (Gameson and Gould, 1975) vary from $0.036-0.045 \mathrm{~cm}^{2} \mathrm{cal}^{-1}$.

\section{Solar Radiation}

The decay rate of faceal coliforms is highly depended on the incident solar radiation lo. Based on field measurements conducted by the National Meteorological Service of Greece, the seasonal variations of the daily average solar intensity was described by an appropriate equation:

$\mathrm{I}_{\mathrm{O}}=120+192 \cdot\left(1-\cos \frac{(\mathrm{d}+16) \cdot 360}{365}\right)$

Io daily average incident solar radiation ( $\left.\mathrm{cal} \mathrm{cm}^{-2} \mathrm{day}^{-1}\right)$

d time (days from January $1^{\text {st }}$ )

In order to predict the daily variation of the concentration of faecal coliforms, the use of the instant intensity of solar radiation and not of the daily average, was employed. Furthermore in order to account for the stochastic character governing the seasonal variation of the intensity of solar radiation, a stochastic coefficient $(\lambda)$ was incorporated in the model which takes values through a uniform possibility density function ranging from 0.8 to 1.2. The final equation for the incident solar radiation used in the model is:

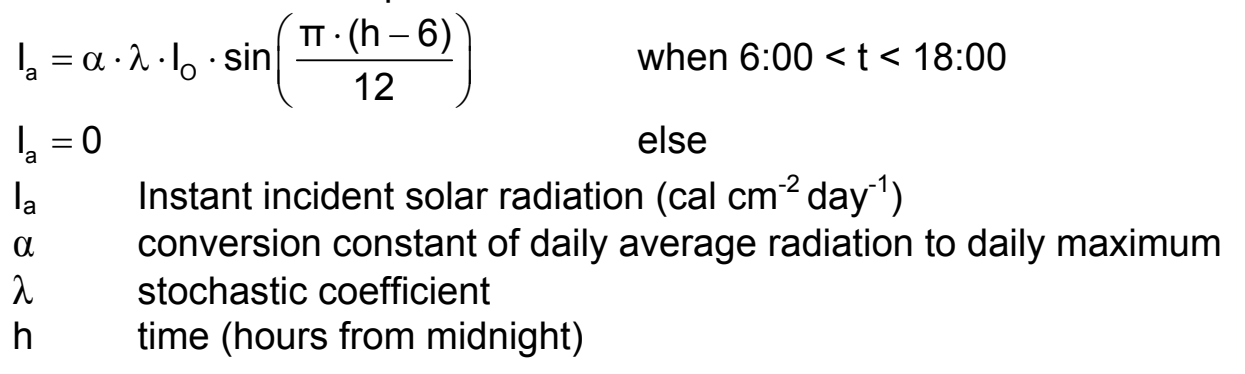

The light attenuation due to water and suspended matter was calculated from equation $\mathrm{I}_{\text {water }}=\mathrm{I}_{\mathrm{a}} \cdot \frac{1-\mathrm{e}^{-\mathrm{K}_{\mathrm{z}} \cdot \mathrm{H}}}{\mathrm{K}_{\mathrm{z}} \cdot \mathrm{H}}$

$I_{\text {water }}$ depth averaged instant intensity of solar radiation (cal $\mathrm{cm}^{-2}$ day $\left.^{-1}\right)$

$\mathrm{K}_{\mathrm{z}} \quad$ light extinction coefficient $\left(\mathrm{m}^{-1}\right)$

$\mathrm{H} \quad$ water column depth $(\mathrm{m})$

The values of $\mathrm{K}_{\mathrm{z}}$ (Bellair et al., 1977) vary randomly from 0.13 to $1.0 \mathrm{~m}^{-1}$.

\section{MODEL APPLICATION - RESULTS}

According to the results of the mathematical model the governing transport mechanism in the rowing course is dispersion, since the flow pattern does not seem to affect considerably the values and the spatial distribution of faecal coliforms concentrations in the rowing course. 
The highest concentrations are observed in an area close to the inlet point of the leading channel, while in areas located in a longer distance the concentrations are significantly lower. Therefore the compliance of the faecal coliforms concentrations of the area close to the leading channel with the Greek and European Legislation is sufficient for the characterization of the entire water body. Figure 3 shows the spatial distribution of faecal coliforms concentrations in terms of $95 \%$ no exceedence probability in the rowing course for month August of a mean hydrological year, where the most aggravated areas, concerning microbial load, are marked with darker colours.

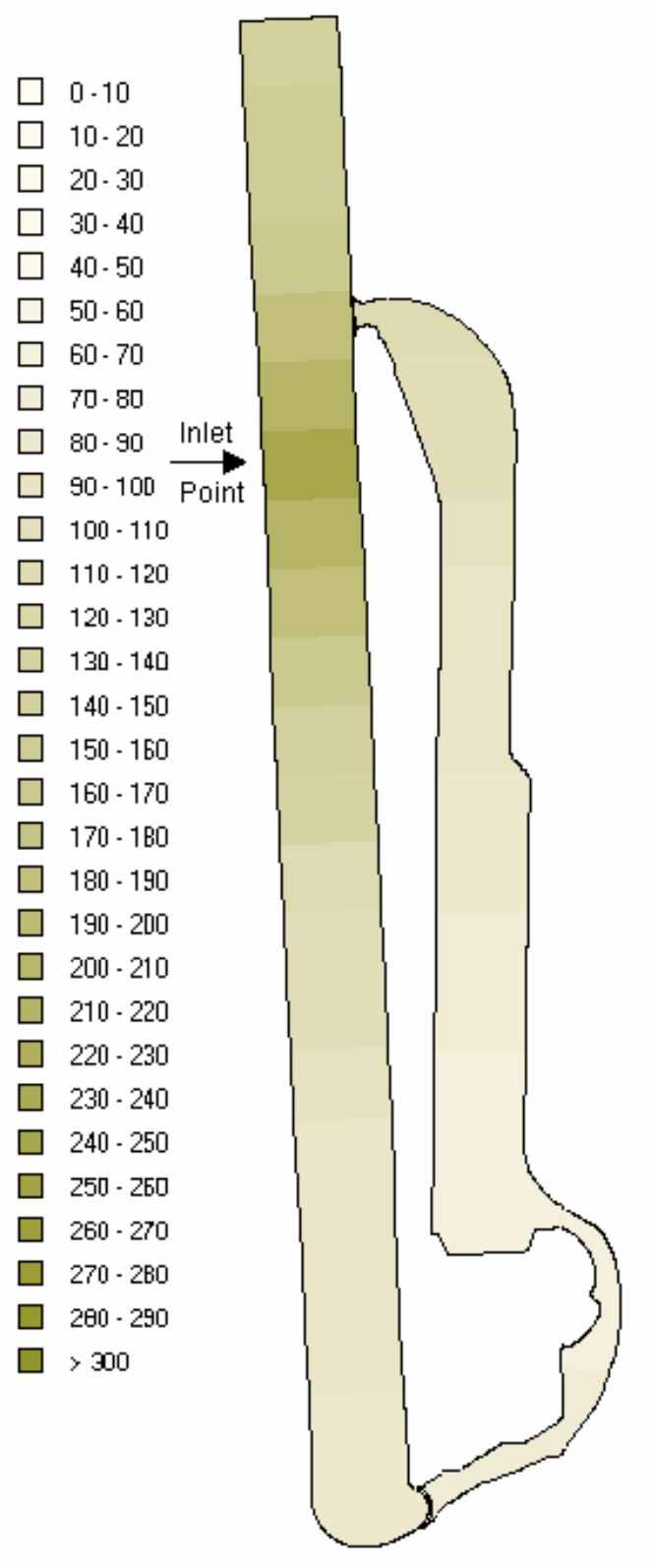

Figure 3. Spatial distribution of C95 concentrations of faecal coliforms for month August of a mean hydrological year
From the application of the mathematical model for several scenarios regarding the discharge of the Makaria spring, it is evidenced that increased inflows entering the rowing course result in higher concentrations of faecal coliforms in the lake. For month August the C95 concentration of faecal coliforms is $125 \mathrm{FC} / 100 \mathrm{ml}$ for an inflow of $242 \mathrm{~m}^{3} \mathrm{hr}^{-1}$, but reaches the value of $1746 \mathrm{FC} / 100 \mathrm{ml}$ for an inflow of $3600 \mathrm{~m}^{3} \mathrm{hr}^{-1}$, which is the maximum flow capacity of the leading channel (Figure 4).

From similar concentration - inflow curves for the other months, it was inferred that for the compliance with the limit of $500 \mathrm{FC} / 100 \mathrm{ml}$ for the $95 \%$ of the samples $(E C, 1976)$ the inflow must not exceed the value of $760 \mathrm{~m}^{3} / \mathrm{hr}$ for the period July - December, while for the period January - June values of inflow even equal with the maximum capacity of the leading channel $\left(3600 \mathrm{~m}^{3} \mathrm{hr}^{-1}\right)$ will not lead to an exceedence of the proposed limit.

Regarding the compliance with the limit of $100 \mathrm{FC} / 100 \mathrm{ml}$ for the $80 \%$ of the samples, the inflow must remain below $660 \mathrm{~m}^{3} \mathrm{hr}^{-1}$ for the period July to December. It should be mentioned that these values of inflows are higher from the discharge of Makaria spring even for a particularly dry hydrological year. However, for the accomplishment of excellent water quality, according to the proposed revision of Directive 76/160 of the European Community which suggests a limit of $250 \mathrm{FC} / 100 \mathrm{ml}$ for the $95 \%$ of the samples, the inflows entering the rowing course should not exceed the value of $2100 \mathrm{~m}^{3} \mathrm{hr}^{-1}$ for the period January - June and the value of $380 \mathrm{~m}^{3} \mathrm{hr}^{-1}$ for the period July December. 


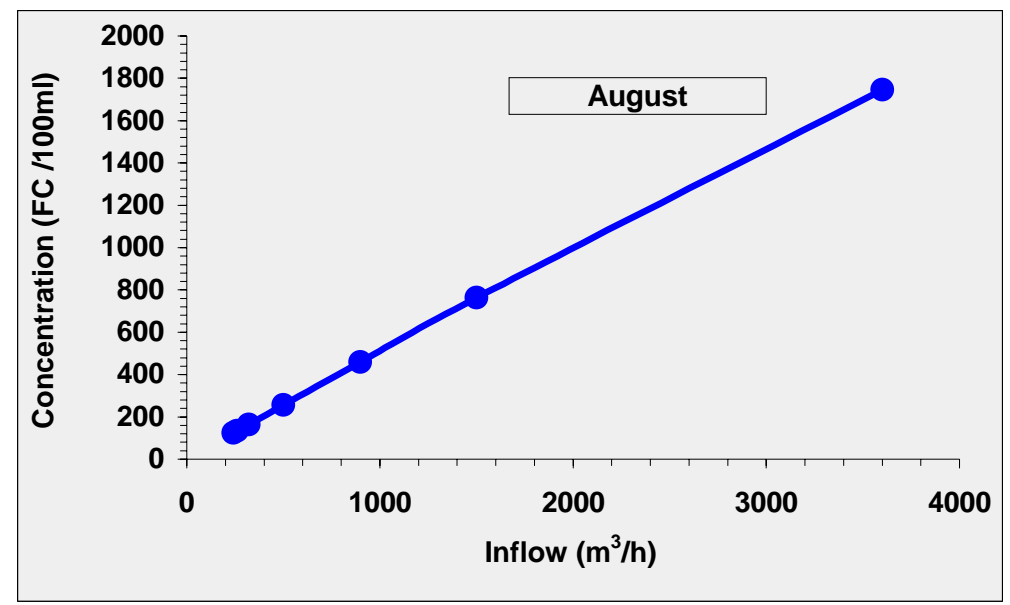

Figure 4. C95 (95\% no exceedence probability) concentrations of faecal coliforms of month August for several values of inflow

Figure 5 presents the results of the mathematical model for three alternative typical hydrological scenarios regarding the discharge of Makaria spring. The concentrations of faecal coliforms refer to the area close to the inlet point where the highest concentrations are observed and from the comparison with the limit of $250 \mathrm{FC} / 100 \mathrm{ml}$ it can be deduced that only few months of the particularly wet hydrological year exceed the above mentioned limit. Nevertheless, the waters of the rowing center are classified in the excellent water quality category, since the compliance with the proposed limit of $250 \mathrm{FC} / 100 \mathrm{ml}$ should be based on an annual and not on a monthly basis.

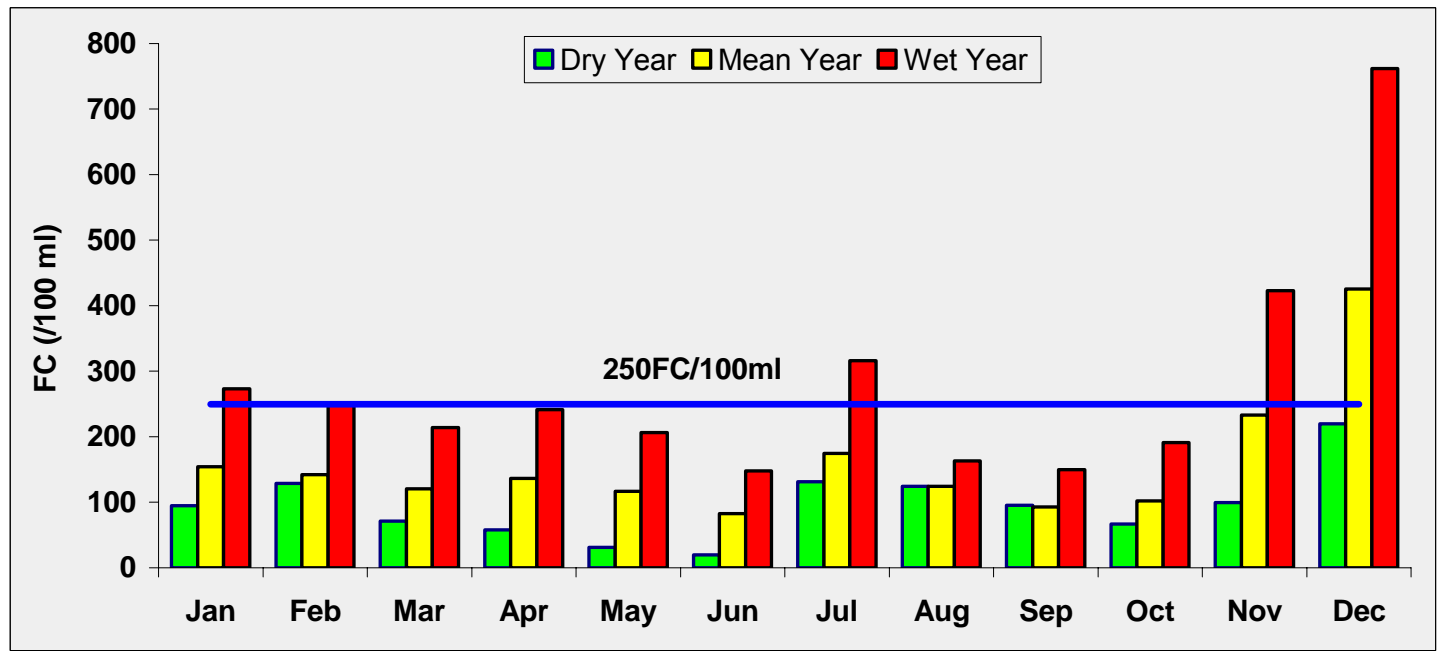

Figure 5. C95 (95\% no exceedence probability) concentrations of faecal coliforms for three typical hydrological years

Finally, as Figure 6 shows, the predicted faecal coliforms concentrations in a representative area of the whole course and the concentrations obtained from the field measurements, in the form of cumulative probability curves, are in a good agreement with each other. 


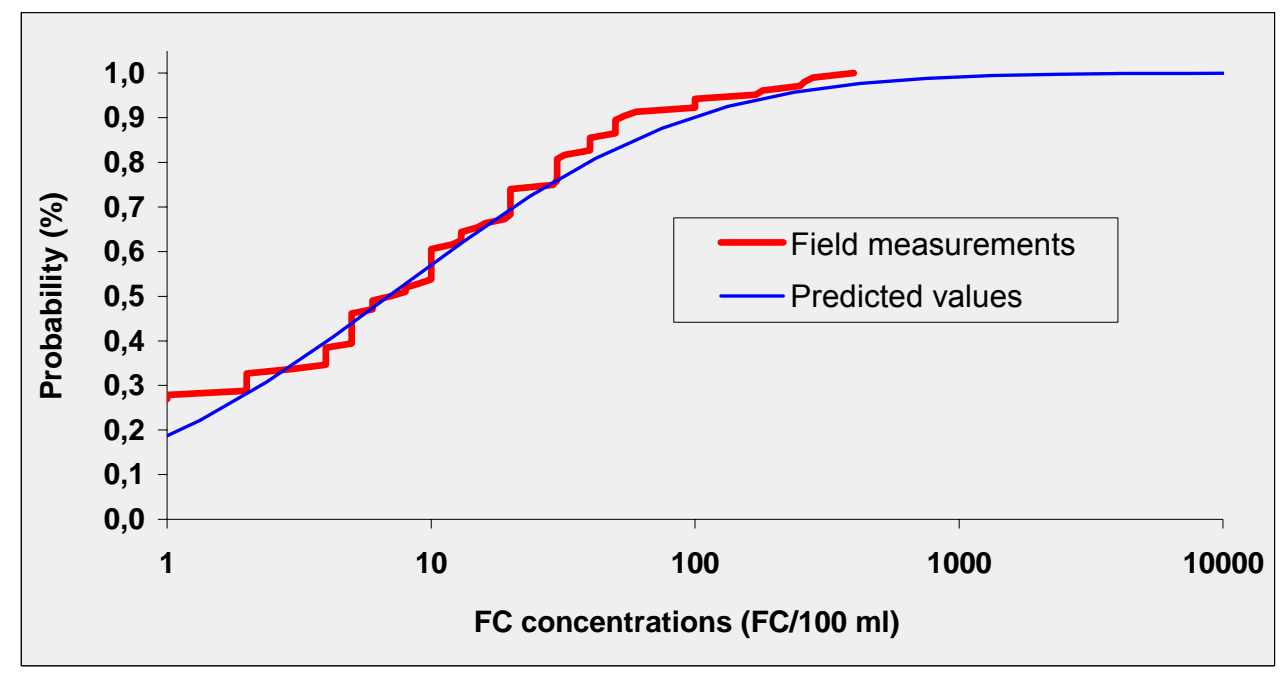

Figure 6. Comparison of field measurements with predicted values

\section{CONCLUSIONS}

For the assessment of the temporal and spatial variation of the faecal coliforms into the Olympic Rowing and Canoeing Center, a mathematical model which incorporates a stochastic approach, was developed. According to the results of the mathematical model, the highest concentrations are observed in an area close to the inlet point of the leading channel, while in areas located in a longer distance the concentrations are decreasing. The anticipated concentration of faecal coliforms, in relation to the proposed revision of the $76 / 160$ European Directive on bathing waters, is lower than $250 \mathrm{FC} / 100 \mathrm{ml}$ for the $95 \%$ of the samples and thus the rowing and canoeing center is sorted in the category of excellent quality waters.

\section{ACKNOWLEDGEMENTS}

This study is part of a research program entitled 'Assessment of : a) the evolution of the trophic state and b) the microbial pollution, of the Olympic Rowing and Canoeing Center of Schinias at Marathonas', financed by the Ministry of Environment.

\section{REFERENCES}

1. Christodoulou G, I. Papakonstantis, A. Stamou, A. Andreadakis, C. Noutsopoulos, E. Romas (2004), "Hydrodynamic characteristics of the new rowing course for the Athens 2004 Olympic Games", presented at the $4^{\text {th }}$ International Symposium on Environmental Hydraulics (Hong Kong, Dec. 2004).

2. EC (1976), Directive 76/160/EEC of 8 December 1975 concerning the quality of bathing waters.

3. Alkan U, Elliot D.J., Evison L.M (1994). "Significance of the effect of solar radiation on the decline of enteric bacterial population in marine waters". Proc. IAWQ Inter: Conf. on Marine.

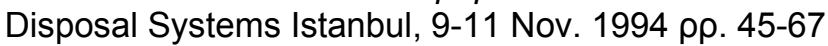

4. Bellair J. T., Parr-Smith. G.A., Wallis IG (1977), "Significance of diurnal variations in fecal coliform die-off rates in the design of ocean outfalls". Journ. WPCF: 2022-2030.

5. Gameson A. L.H and Gould D.J. (1975), "Effect of solar radiation on the mortality of some terrestrial bacteria in sea water" in Discharge of sewage from sea outfalls" Pergamon Press. Oxford, 209-219. 